\title{
PERUBAHAN PESANTREN ANTARA EFEKTIFITAS DAN INEFEKTIFITAS
}

\author{
Aminatuz Zahroh \\ Institut Agama Islam Syarifuddin Lumajang, Indonesia \\ E-mail: aminatuzzahrosyarif@gmail.com
}

\begin{abstract}
Abstrak: Sejarah berujar bahwa pesantren dengan segala tipologinya selalu konsisten dengan tri dharmanya yaitu: peningkatan keimanan dan ketaqwaan terhadap Allah SWT, pengembangan keilmuan yang bermanfaat dan pengabdian terhadap agama masyarakat dan negara. Untuk melaksanakan tri dharmanya dengan baik, pesantren melakukan perubahan diberbagai bidang yang dikelolanya. Seperti dalam kurikulum, kepemimpinan, sumberdaya manusia dan budayanya. Perubahan tersebut mutlak perlu dilakukan oleh pesantren, karena pesantren merupakan lembaga pendidikan kedua setelah keluarga dan sebagai lembaga yang mempersiapkan anak ketika pulang kemasyarakat. Perubahan ini mempertimbangkan aspek-aspek lokalitas kepesantrenan dan keindonesiaan. Perbincangan tentang perubahan dalam rajutan pesantren tidak akan terlepas dari bagaimana sisi terang dan gelap perubahan pesantren, problem pesantren dalam menghadapinya, langkah-langkah efektif dan inefektif yang selama ini sudah banyak dilakukan oleh pesantren serta tawaran solutif perubahan pesantren. Tulisan ini berusaha menawarkan jalan keluar (way out) dari permasalahan tersebut.
\end{abstract}

Kata kunci: perubahan, pesantren, efektifitas, inefektifitas

\section{Pendahuluan}

Membincangkan pesantren adalah sebuah keniscayaan sejarah yang senantiasa mengalir dari hulu ke hilir. Ibarat air pegunungan, pesantren merupakan pembahasan yang luas, mengalir dan tidak pernah terhenti.Untuk itu tidak pernah ada kata absolut dan final dalam kajian tersebut. Diskursus pesantren akan senantiasa mengalir tidak mengenal kata akhir.

Secara historis kultural, pesantren merupakan salah satu potret institusi penting bagi masyarakat Indonesia. Hal ini dapat dilihat dari diterapkannya tri darma pesantren yaitu peningkatan pengetahuan agama dalam (tafaqquh fi ad-din), penyebarluasannya (dakwah) dan pemberdayaan masyarakat. ${ }^{1}$

Secara sosial, pesantren telah memainkan peran penting dalam penyebaran Islam di Indonesia. Ia menjadi sebuah media sosialisasi formal dimana keyakinan-keyakinan, norma-norma dan nilai-nilai Islam di trasmisikan dan ditanamkan melalui pembelajaran dan pembiasaan. ${ }^{2}$

Secara sosial historis, pada masa pertumbuhannya, madrasah dan pesantren merupakan tradisi sistem pendidikan bercorak fiqh. ${ }^{3}$ Bercermin pada hal ini, maka pesantren pada perkembangan saat ini, dipandang dari fokus pendidikannya, dapat dikelompokkan menjadi pesantren yang mefokuskan pendidikannya dengan spesialisasi dalam bidang keagamaan tetapi

\footnotetext{
${ }_{1}$ Derektorat Jenderal Kelembagaan Agama Islam, Pedoman Tatalaksana Pengembangan Agri Bisnis di Pondok Pesantren (Jakarta: Depertemen Agama RI, 2003), vii

${ }^{2}$ Endang Turmudzi, Perselingkuban Kiai dan Kekusaan (Yogyakarta: LKiS, 2004), 37

${ }^{3}$ Suwito, Fauzan, Sejarah Sosial Pendidikan Islam (Jakarta: Prenada Media, 2005), 207 
ada juga yang hanya memberikan pelajaran agama sebagai nilai dan tidak sampai spesialisasi tetapi santri memiliki kesadaran yang tinggi terhadap pentingnya agama dalam kehidupan. ${ }^{4}$

Pesantren terus berupaya mengadakan perubahan dan pengembangan pendidikan berdasarkan Undang-Undang nomor 20 tahun 2003 tentang Sistem Pendidikan Nasional, Peraturan Pemerintah nomor 32 tahun 2013 tentang Standar Nasional Pendidikan dan Peraturan Pemerintah nomor 55 tahun 2007 tentang Pendidikan Agama dan Pendidikan Keagamaan. Maka sudah seharusnya pondok pesantren melakukan pembenahan dalam semua aspek dengan tiga syarat yaitu menyesuaikan dengan perkembangan zaman, merespon harapan masyarakat tapi tetap menjaga kekhasan sebagai lembaga pendidikan Islam. ${ }^{5}$

Upaya tersebut ternyata membuat respon masyarakat terhadap pesantren sangat baik sehingga jumlah pesantren di Indonesia dan santri terus meningkat,sehingga pada tahun 2011 2012 jumlah pesantren di Indonesia mencapai 27.230 pesantren dengan jumlah santri seluruhnya 3.759.198 santri. ${ }^{6}$ Pada tahun 2011-2012, jumlah pesantren di Jawa timur saja mencapai 6.003 dan pada tahun 2013 mencapai 6.561 pesantren dengan jumlah santri 950.899 santri. $^{7} \mathrm{Hal}$ ini menunjukkan bahwa jumlah pesantren di Jawa Timur bertambah 558 dalam waktu satu tahun. Dengan demikian pesantren di Jawa Timur sangat layak dan menarik untuk diteliti.

Deskripsi di atas menunjukkan bahwa meskipun banyak terjadi perubahan di berbagai aspek kehidupan di masyarakat, pesantren tetap berpegang teguh pada elemen-elemennya yang esensial sehingga masyarakat tetap memberikan kepercayaannya pada pesantren. Ada tiga elemen esensial yang membentuk pesantren (1) Pola kepemimpinan pesantren yang mandiri dan tidak terkooptasi oleh Negara (2) Kitab-kitab rujukan umum yang selalu digunakan dari berbagai abad (3) Sistem nilai yang di gunakan adalah bagian masyarakat luas. ${ }^{8}$

Perubahan apapun yang ditujukan untuk mampu membangun dan mengembangkan pesantren merupakan suatu hal yang patut mendapatkan apresiasi dan elaborasi secara memadai.Harus diakui, ini memerlukan kritik, upaya rekonstruksi, bahkan dekonstruksi pikiranpikiran yang sudah ada.

Dalam melihat persoalan perubahan pesantren perlu digunakan dua tataran institusional dan tataran ideal. Pada tataran institusional akar-akar perubahan di pesantren sudah ada, sekalipun itu sangat sederhana dan perlu dikembangkan. Sedangkan dari tataran ideal (visi), kita agak mengalami kesulitan, sebab sebuah visi dari pesantren menuntut adanya kemampuan pesantren

\footnotetext{
${ }^{4}$ Abdur Rahman Wahid, Prisma Pemikiran Gus Dur (Yogyakarta: LKiS 1999), 114-115

5 Abd Halim Soebahar, Kebijakan Pendidikan Islam dari Ordonansi Guru sampai UU Sisdiknas (Jakarta: Raja Grafindo Persada, 2013), 42.

${ }^{6}$ www.pendis.kemenag.go.id. Diakses 11/4/2018.

${ }^{7}$ www.jatim.kemenag.go.id. Diakses 11/4/2018.

8 Abdur Rahman Wahid, Podok Pesantren Masa Depan, dalam Masdar Hilmy, Pendidikan Islam dan Tradisi Ilmiah (Surabaya: Pustaka Idea, 2013), 163

108 | Tarbiyatuna: Jurnal Pendidikan Islam; Volume 13, Nomor 2, Agustus 2020, 107-122 p-ISSN: 2085-6539; e-ISSN: 2242-4579
} 
menyerap khazanah dari luar sehingga muncul sinergi antara khazanah pesantren dengan khazanah luar pesantren.

\section{Pesantren: Unsur dan Tipologinya}

Pesantren telah berubah, sedang mulai perubahan dan akan berubah. Dalam hal ini pesantren yang sudah lama memahami arti penting suatu perubahan ia telah berubah. Pesantren yang baru menyadari pentingnya perubahan ia sedang memulai perubahan. Sedangkan pesantren yang masih mencoba memahami pentingnya perubahan ia baru akan berubah. ${ }^{9}$

Menurut Manfred Ziemek, pesantren adalah lembaga pendidikan tradisional Islam untuk mamahami, menghayati, dan mangamalkan ajaran agama Islam (tafaqquh fiddin) dengan menekankan moral agama Islam sebagai pedoman hidup sehari-hari, baik dalam hidup beragama, bemasyarakat dan bernegara.

Secara etimologi, istilah pesantren berasal dari kata santri, yang dengan awalan pe- dan akhiran -an berarti tempat tinggal para santri. Kata "santri" juga merupakan penggabungan antara suku kata sant (manusia baik) dan tra (suka menolong), sehingga kata pesantren dapat diartikan sebagai tempat mendidik manusia yang baik. ${ }^{10} \mathrm{Hal}$ ini juga berarti pesantren diharapkan mampu merubah anak tidak baik menjadi baik.

Unsur-unsur kunci pesantren adalah lembaga pesantren itu sendiri, peranan dan kepribadian kiai yang sangat menentukan dan karismatik, sikap hormat dan kepatuhan terhadap kiai dan pengarang kitab. ${ }^{11}$ Unsur-unsur kunci inilah yang membadakan pesantren dengan lembaga pendidikan lainnya.

Dilihat dari kitab-kitab yang dikaji dan sistem pendidikannya maka, tipologi pesantren terbagi menjadi: salafiyah, kholafiyah dan salafiyah kholafiyah. Adapun jumlah pesantren di Indonesia pada Tahun 2012 dilihat dari tipologinya dapat divisualisasikan sebagai berikut:

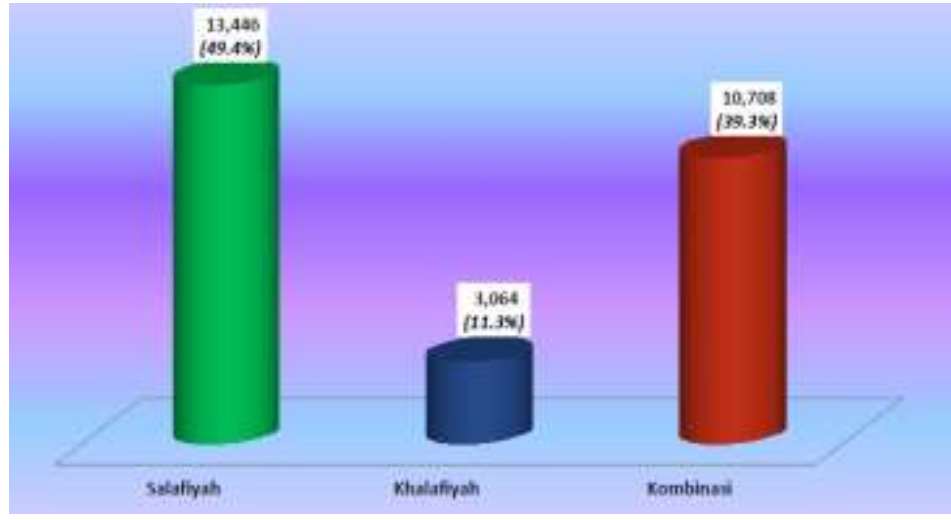

Figur Kategori Pesantren

\footnotetext{
${ }^{9}$ A. Halim, RR Suhartimi, M. Choirul Alif, A. Suharto, Manajemen Pesantren (Yogyakarta: Pustaka Pesantren, 2005), v.

${ }^{10}$ Manfred Ziemek, Pesantren dalam Perubahan Sosial, terj. Butche B. Soendjojo (Jakarta: P3M, 1986), 8

${ }^{11}$ Martin Van Bruinessen, Kitab Kuning, Pesantren dan Tarekat (Yogyakarta: Gading Publishing, 2012), 86 
Dari visualisasi di atas jelaslah bahwa pesantren salafiyah berada di peringkat tertinggi, diikuti oleh pesantren kombinasi dan pesantren khalafiyah. ${ }^{12}$

Sedangkan dilihat dari model pengelolahannya pesantren terbagi menjadi dua, yaitu: Pesantren pribadi dan Institusional. Dilihat dari pendekatan wilayah yang digunakan maka pesantren terbagi menjadi pesantren pedesaan (rural pesantren), dan pesantren perkotaan (urban pesantren). ${ }^{13}$

\section{Ciri Khas Pesantren}

Apapun tipologinya pesantren tetap menanamkan pancajiwa yaitu keihklasan, kesederhanaan, kemandirian, ukbuwah Islamiyah dan kebebasan. ${ }^{14}$ Meskipun perubahan terjadi dalam berbagai aspek kehidupan, pesantren tetap memiliki ciri khas sebagai berikut:

1. Kebersamaan kiai bersama santri.

Hal ini disebabkan karena kiai dan santri tinggal dalam satu area pesantren dan banyak kegiatan yang melibatkan kiai dan santri.

2. Kesederhanaan

Hal ini dimaksudkan agar santri tangguh dalam menghadapi tantangan zaman.

3. Kesetaraan untuk semua santri.

Dalam pesantren semua santri diperlakukan sama oleh kiai dan para ustadz, meskipun dari tingkat ekonomi dan tingkat sosial yang berbeda.

4. Mujahadah dan riyadhah menjadi mudah, karena hal tersebut ditanamkan dan dibiasakan terhadap santri dengan melakukannya bersama-sama.

5. Pendidikan formal dan diniyah yang terpadu, sehingga dapat saling melengkapi dan lebih mudah mencapai tujuan pendidikan di pesantren.

6. Ilmu agama dapat dipelajari oleh santri secara terpadu (teori dan prakteknya).

Keterpaduan sistem pendidikan di pesantren sangat mendukung hal tersebut. Sehingga di pesantren tidak terjadi kesenjangan antara teori dan praktek (antara ilmu dan amal)

7. Penerapan Ta'lim (transfer of knowledge) dan Tarbiyah (transfer of value) secara terpadu.

Ta'lim di pesantren lebih mudah diterapkan karena banyak orang alim (kiai dan para ustadz) yang bisa dijadikan sebagai tempat bertanya tentang masalah-masalah yang membutuhkan penyelesaian. Tarbiyah juga lebih mudah dilakukan di pesantren, karena banyak orang dewasa (kiai dan para ustadz) yang bisa dijadikan teladan dalam penerapan nilai-nilai Islam.

12 Bagian Perencanaan dan Sistem Informasi, Secretariat Ditjen Pendidikan Islam Kementrian Agama RI, http://www.pendis.Kemenag.go.id/

13 Azyumardi Azra, CBE, Pesantren Masa Kontemporer (Manajemen Sebagai Holding) dalam makalah untuk forum Dosen IAIN Jember 16 September 2016, 4.

14 Abdul Halim Soebahar, Kebijakan Pendididkan Islam dari Ordonansi Guru Sampai UU SISDIKNAS (Jakarta: Raja Grafindo, 2017) 42-43.

110 | Tarbiyatuna: Jurnal Pendidikan Islam; Volume 13, Nomor 2, Agustus 2020, 107-122 p-ISSN: 2085-6539; e-ISSN: 2242-4579 
8. Kurikulum pendidikan agama dari tingkat bawah sampai atas terpadu.

Keterpaduan kurikulum ini terlihat jelas dalam kurikulum pesantren, madrasah diniyah dan madrasah formal di dalamnya.

Pondok pesantren juga disatukan melalui persamaan tata hubungan yang khas dalam kependidikan dan kemasyarakatan, yaitu :

1. Hubungan yang dekat antara kiai dan santri

2. Ketaatan santri yang tinggi kepada kiai

3. Hidup hemat dan sederhana

4. Tingginya semangat kemandirian para santri

5. Berkembangnya suasana persaudaraan dan tolong menolong

6. Tertanamnya sikap istiqomah ${ }^{15}$

\section{Landasan Religius Perubahan di Pesantren}

Empat hal yang harus diperhatikan dalam gerak pendidikan yaitu: pertumbuhan (growth), perubahan (change), pembaharuan dan pengembangan (development) dan berkelanjutan dan ketahanan (sustainable) ${ }^{16}$. Adapun perubahan di Pesantren juga tidak dapat dihindari. Bahkan pesantren harus menghadapi perubahan itu dengan tetap berlandaskan pada:

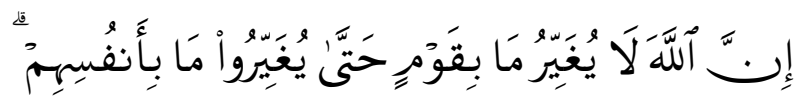

Artinya: Sesungguhnya Allah tidak merobah keadaan sesuatu kaum sehingga mereka merobah keadaan yang ada pada diri mereka sendiri.

Pada umumnya perubahan di pesantren didasarkan pada prinsip " continuity and change".Dalam bahasa pesantrennya dikenal dengan istilah

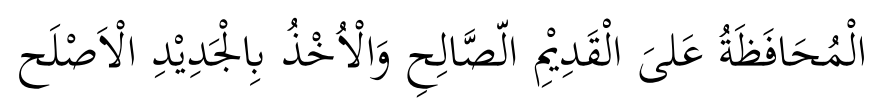

Pesantren akan terus melakukan perubahan, adopsi dan inovasi bahkan memunculkan halhal yang baru dengan tetap mempertahankan hal lama yang baik dan bermanfaat. ${ }^{17} \mathrm{Hal}$ inilah yang menyebabkan pesantren terus berkembang sesuai dengan tipologinya masing-masing.

\footnotetext{
${ }^{15}$ Soebahar, Kebijakan Pendididkan Islam, 14

16 Mujammil Qamar, Manajemen Pendidikan Islam (Strategi Baru Pengelolaan Lembaga Pendidikan Islam) (Jakarta: Erlangga, 2007), 47

${ }^{17}$ Soebahar, Kebijakan, 182.
} 


\section{Sisi Terang dan Sisi Gelap Perubahan Pesantren}

Beberapa kekuatan (sisi terang) perubahan menjadikan beberapa pesantren semakin survive. Tetapi beberapa kekuatan perubahan tersebut sekaligus menjadi kelemahan (sisi gelap) bagi beberapa pesantren yang lain. Hal ini dapat diperjelas sebagai berikut:

1. Kekuatan kompetitif.

Pesantren yang dapat menghadapi dan mengimbangi kompetitor dalam kapasitas, dan kapabilitasnya untuk mengembangkan produk, dan pelayanan yang baik maka pesantren tersebut akan survive. Tapi jika tidak mampu mengimbanginya, maka akan terjadi sebaliknya.

2. Kekuatan global, politik dan ekonomi

Hal Ini bisa mengakibatkan pesantren merubah pelayanan dan menghasilkan output yang lebih baik. Tapi sebaliknya, kekuatan ini bisa berubah menjadi kelemahan bagi pesantren yang tidak bisa memberikan pelayanan dan menghasilkan out put yang lebih baik.

3. Kekuatan sosial dan demografik

Perubahan-perubahan dalam karakteristik demografik dan masyarakat, kekuatan kerja dan potensi yang tinggi dari para personil pesantren telah membuat para pengelola pesantren merubah cara memanaj pesantren dan mempelajari bagaimana bisa memahami, supervisi dan memotivasi bawahan dan santri lebih efektif. Akan tetapi banyak juga pesantren yang tidak mampu memanfaatkan hal-hal tersebut untuk bisa memanaj pesantren lebih efektif dan meningkatkan mutu pesantren.

4. Kekuatan Etis

Kekuatan etis sangat penting bagi pesantren dalam mengambil langkah yang mendukung sikap etis dalam menghadapi pemerintahan, permintaan sosial politik yang meningkat dan sikap kerja sama yang jujur dan lebih bertanggungjawab. ${ }^{18}$ Akan tetapi di beberapa pesantren sikap etis ini menjadikan pesantren menjauh dari pemerintah dan permintaan sosial politik tanpa mempertimbangkan sikap jujur dan tanggung jawab pelaku politik.

\section{Problem Pesantren dalam Menghadapi Perubahan}

Terdapat beberapa hal yang tengah dihadapi pesantren dalam melakukan pengembangannya, yaitu:

1. Image pesantren sebagai sebuah lembaga pendidikan yang tradisional, tidak modern, informal, dan bahkan teropinikan sebagai lembaga yang melahirkan terorisme telah mempengaruhi pola

18 Gareth, R. ,Organizational, 303- 305.

112 | Tarbiyatuna: Jurnal Pendidikan Islam; Volume 13, Nomor 2, Agustus 2020, 107-122 p-ISSN: 2085-6539; e-ISSN: 2242-4579 
pikir masyarakat untuk meninggalkan dunia pesantren. Hal tersebut merupakan sebuah tantangan yang harus dijawab sesegera mungkin oleh dunia pesantren dewasa ini.

2. Sarana dan prasarana penunjang yang terlihat masih kurang memadai. Bukan saja dari segi infrastruktur bangunan yang harus segera dibenahi, melainkan terdapat pula yang masih kekurangan ruangan pondok (asrama) sebagai tempat menetapnya santri. Selama ini kehidupan pondok pesantren yang penuh kesederhanaan dan kebersahajaannya tampak masih memerlukan tingkat penyadaran dalam melaksanakan pola hidup yang bersih dan sehat yang didorong oleh penataan dan penyediaan sarana dan prasarana yang layak dan memadai.

3. Sumber daya manusia. Sekalipun sumber daya manusia dalam bidang keagamaan tidak dapat diragukan lagi, tetapi dalam rangka meningkatkan eksistensi dan peranan pondok pesantren dalam bidang kehidupan sosial masyarakat, diperlukan perhatian yang serius. Penyediaan dan peningkatan sumber daya manusia dalam bidang manajemen kelembagaan serta bidang-bidang yang berkaitan dengan kehidupan sosial masyarakat, mesti menjadi pertimbangan pesantren.

4. Aksesibilitas dan networking. Merupakan salah satu kebutuhan untuk pengembangan pesantren. Penguasaan akses dan networking dunia pesantren masih terlihat lemah, terutama sekali pesantren-pesantren yang berada di daerah pelosok dan kecil. Ketimpangan antar pesantren besar dan pesantren kecil begitu terlihat dengan jelas.

5. Manajemen kelembagaan. Manajemen merupakan unsur penting dalam pengelolaan pesantren. Pada saat ini masih terlihat bahwa pondok pesantren dikelola secara tradisional apalagi dalam penguasaan informasi dan teknologi yang masih belum optimal. Hal tersebut dapat dilihat dalam proses pendokumentasian (data base) santri dan alumni pondok pesantren yang masih kurang terstruktur.

6. Kemandirian ekonomi kelembagaan. Kebutuhan keuangan selalu menjadi kendala dalam melakukan aktivitas pesantren, baik yang berkaitan dengan kebutuhan pengembangan pesantren maupun dalam proses aktivitas keseharian pesantren. Tidak sedikit proses pembangunan pesantren berjalan dalam waktu lama karena menunggu sumbangan atau donasi dari pihak luar bahkan harus melakukan penggalangan dana di pinggir jalan.

7. Kurikulum yang berorientasi life skills santri dan masyarakat. Pesantren masih berkonsentrasi pada peningkatan wawasan dan pengalaman keagamaan santri dan masyarakat. Apabila melihat tantangan kedepan yang semakin berat, peningkatan kapasitas santri dan masyarakat tidak cukup. 


\section{Sketsa dan Langkah-Langkah Efektif dan Inefektif Pesantren}

Langkah-langkah efektif yang harus dilakukan oleh pimpinan pesantren dalam menyikapi perubahan adalah sebagai berikut:

1. Memberikan bantuan atau dukungan terhadap perubahan pesantren yang akan dilakukan

2. Meningkatkan kooperasi atau kerja sama untuk mendukung perubahan

3. Menerangkan situasi, kondisi dan proses perubahan

4. Memunculkan masalah penolakan terhadap perubahan ke permukaan untuk dibahas

5. Menanggapi penolakan terhadap perubahan secara serius

6. Melibatkan semua individu dalam melakukan perubahan

7. Melakukan negoisasi agar perubahan didukung oleh semua fihak baik di dalam pesantren maupun di luar pesantren

Adapun langkah-langkah tidak efektif dalam menyikapi perubahan adalah sebagai berikut:

1. Mempertahankan diri pada kondisi yang lama

2. Memberikan nasihat yang tidak perlu sehingga memunculkan keengganan untuk menerima perubahan

3. Membujuk dan memengaruhi orang lain supaya menolak perubahan

4. Tidak menyetujui dan menolak perubahan secara terbuka ${ }^{19}$

Sebab-sebab penolakan terhadap perubahan sebagai berikut:

1. Kepentingan pribadi yang picik seperti jika menerima perubahan, maka kedudukannya tergeser bahkan terancam di-non aktif-kan

2. Salah pengertian dan kurang percaya terhadap perubahan yang akan dilakukan pimpinan pesantren

3. Penilaian yang negatif terhadap perubahan

4. Toleransi yang rendah terhadap perubahan ${ }^{20}$

\section{Tawaran Solutif Perubahan Pesantren}

1. Tawaran Konseptual

Untuk keberhasilan perubahan pesantren, pimpinan pesantren dapat melakukan beberapa tawaran konseptual sebagai berikut:

a. Meningkatkan pengetahuan dan wawasan santri terhadap perubahan melalui pendidikan, pembelajaran dan pelatihan

b. Menjaga komunikasi yang baik dengan semua personil pesantren

${ }^{19}$ Edy Sutrisno, Budaya Organisasi, 245

${ }^{20}$ James L. Gibson, James H. Donnelly, John N. Ivancevich, Fundamental of Management, Terj. Sularno Tjipto Wardoyo, Imam Nur Wawan, Management Edisi 9 Jilid 2 (Jakarta: Erlangga, 1997), 128-129

114 | Tarbiyatuna: Jurnal Pendidikan Islam; Volume 13, Nomor 2, Agustus 2020, 107-122 p-ISSN: 2085-6539; e-ISSN: 2242-4579 
c. Meningkatkan partisipasi dan keterlibatan langsung dalam melakukan perubahan

d. Menyediakan fasilitas dan penunjang yang dibutuhkan dalam melakukan perubahan

e. Lakukan negoisasi dan kesepakatan dengan fihak yang terkait dengan perubahan

f. Memilih seseorang untuk menjadi anggotateam perubahan

g. Lakukan paksaan implisit dan eksplisit dengan memperketat peraturan ${ }^{21}$

h. Adapun Langkah-langkah menuju perubahan organisasi dengan cara:

i. Menetapkan visi yang jelas dan arah strategis

j. Mengembangkan pengukuran kinerja yang jelas

k. Melakukan tindak lanjut menuju pada pencapaian tujuan

1. Menghargai kinerja atas dasar keadilan

m. Menciptakan lingkungan kerja yang lebih terbuka dan transparan

n. Menghapuskan politik dalam pesantren

o. Mengembangkan team spirit yang kuat melalui sejumlah core values.22

Adapun konsep kepemimpinan pesantren seharusnya memiliki arah pengembangan pada terbentuknya:

a. Ummat yang bersatu (ummatan wabidah)

b. Ummat yang moderat (ummatan wasathan)

c. Ummat yang terbaik (khoiru ummah)

d. Negara yang makmur (baldatun thoyyibatun)

e. Ummat yang lurus dijalan Allah (ummatan muqtasidab). ${ }^{23}$

Kepemimpinan pesantren dapat juga diarahkan dan dikembangkan menuju hal-hal berikut: $^{24}$

a. Membentuk ummah (takwinul ummah)

b. Membentuk kepribadian (takwin Asy-syakhshiyyah)

c. Membentuk semangat berjamaah (takwin ruuh al-jamaa'ah)

d. Gerakan penyelamatan (barakah al-inqaadz)

e. Orang yang mendapatkan petunjuk (al-mubtaduun)

f. Kesuksesan (al-falah)

Prinsip-prinsip kepemimpinan profetik sebagai berikut: ${ }^{25}$

a. Prinsip Taubid

b. Prinsip Syura (musyawarah)

${ }^{21}$ Gibson, Fundamental of Management, 130.

22 Uha, Budaya Organisasi, 65

${ }^{23}$ Ali Nurdin, Quranic Society (Jakarta: Erlangga, 2006), 100

${ }^{24}$ Irwan Prayitno, Datuak Rajo Bandaro Basa, Kepribadian Dai (Jakarta: Pustaka Tarbiatuna, 2005), 291

25 Shoni Rahmatullah Amrozi, The Power Of Rasulullab's Leadership (Yogyakarta: Sabil, 2012), 142-157 

c. Prinsip Al-Adalah (adil)
d. Prinsip Al-Hurriyah (kebebasan)

Kepemimpinan profetik dapat diterapkan dengan menggunakan strategi sebagai berikut:

a. Pilihlah langkah strategik (Be Strategic)

b. Bekerja samalah (Find Champions/Make Alliance)

c. Bersikaplah sikap fleksibel dengan menggunakan tahapan-tahapan yang strategik (Be Flexible-Use a Range of Strategies)

d. Dapatkan kepercayaan dari orang lain (Be Credible)

e. Ciptakan komunikasi dengan baik (Comunicate)

f. Manajlah dan dukunglah tim kamu (Manage and Support Your Team)

g. Lakukan penelitian yang berfokus pada pekerjaan dari unit tertentu (Take a Research Focus to the Work of the Unit). ${ }^{26}$

Adapun dalam pengembangan kurikulum pesantren memperhatikan hal-hal antara lain, mampu berperan sebagai abdullah, khalifah fi al-ardi dan musta'mir fil-ardi. Hal ini dapat di visualisasikan sebagai berikut:

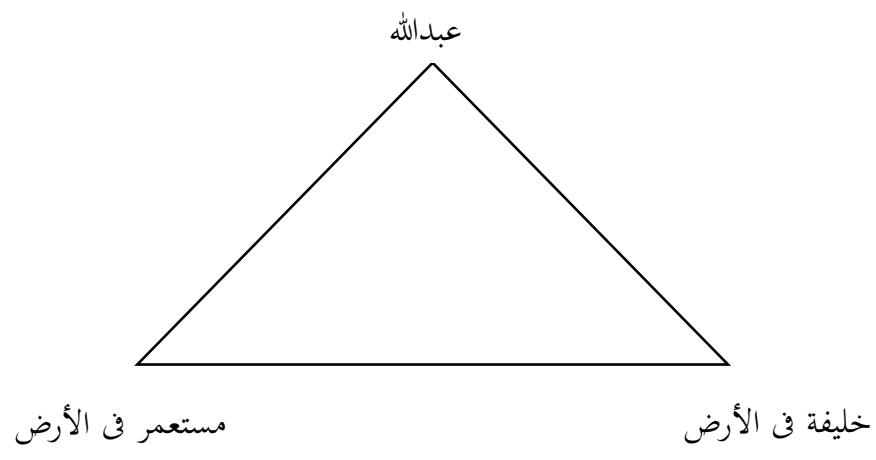

Figur Pembentukan Peran Santri.

a. Ulul albab yaitu: yang memiliki karakteristik daya pikir yang tinggi, dzikir yang mantap dan amal yang sholeh.

b. Rahmatan li al-'alamin yaitu yang kehidupanya mendatangkan rahmat bagi alam semesta. Dalam hal ini siswa diharapkan menjadi orang yang terbaik karena memberi manfaat bagi orang lain.

${ }^{26}$ David Baume dan Peter Kahn, Enhancing Staff and Educational Development (London: Routledge Falmer, 2004), 45-51 
Arah pengembangan kurikulum seharusnya didasarkan pada konsep istirja' agar dapat sebagaiman divisualisasikan sebagai berikut:

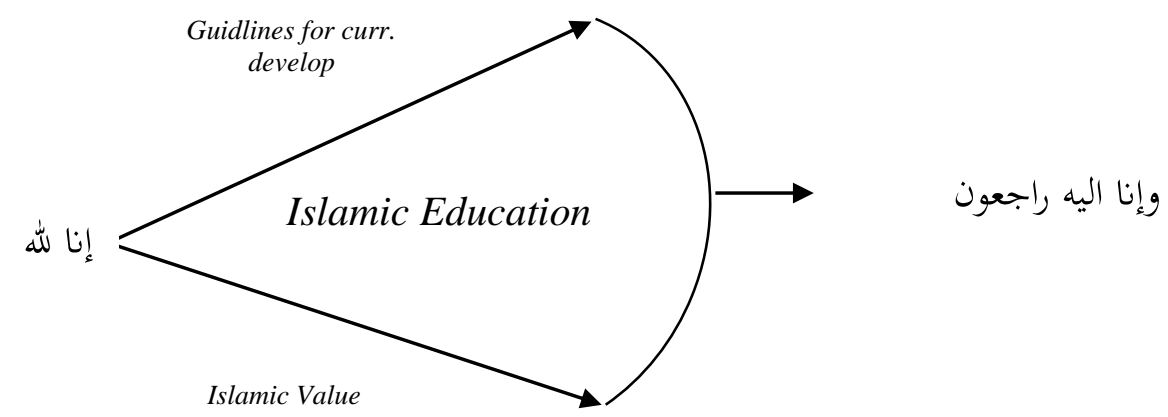

Figure Pengembangan Konsep Istirja'

Di dalam design kurikulum di beberapa pesantren kadang-kadang meniru kurikulumnya pesantren lain padahal design kurikulum seharusnya berdasarkan pada visi dan misi dari pesantren yang berkaitan. Dan mengimplementasinya sesuai dengan situasi dan kebutuhan pesantren. Jangan meniru visi dan misi kurikulum pesantren lain

Pengembangan kurikulum di pesantren dapat di implementasikan dengan berdasarkan berdasarkan prinsip continuity and change sebagai berikut:

$$
\text { المحافظة على القديم الصالح و الأخذ بالحديد الأصلح }
$$

Artinya : menjaga sesuatu yang lama baik dan mengambil sesuatu yang lebih baik.

Sering kita lihat, implementasi kurikulum di beberapa pesantren sering kali mengikuti trend, tidak berdasarkan visi dan misi pesantren itu sendiri. Jika aktivitas mereka mengikuti trend aktivitas pesantren yang lain maka implementasi kurikulum tersebut tidak bisa mencapai visi dan misinya.

Implementasi pengembangan kurikulum di pesantren seharusnya melalui beberapa tahap sebagai berikut:

Pemetaan masalah $\longrightarrow$ Research $\longrightarrow$ Pengembangan Kurikulum

Tahap Pengembangan Kurikulum di Pesantren

2. Tawaran Operasional

Adapun untuk melaksanakan tawaran konseptual tersebut dapat dilakukan beberapa tawaran operasional sebagai berikut: 
a. Merebut image dalam persaingan hal ini akan menciptakan perilaku pribadi maupun perilaku sosial dipengaruhi konsep komunikasi pemasaran. Jadi keberhasilan pemasaran harus dijaga sepanjang masa.

b. Memberi merk dilakukan dengan cara sebagai berikut:

1) Terlebih dulu mengenali dan menentukan profile pondok pesantren

2) Mengenali profil halayak dengan baik. Halayak ini dapat saja diciptakan dan dibentuk diantara masyarakat yang majemuk atau halayak ini sepenuhnya sudah lama eksis, pengenalan dan fokus terhadap layak akan sangat membantu mengarahkan merk.

3) Mengenali terlebih dulu problematika masyarakat, kemudian memfokuskan diri terhadap kelompok atau komunitas tertentu yang akan ditangani

4) Mendesain model pondok pesantren yang match dengan sasaran itu. Jadi strategi maupun kegiatan ponpes sengaja dirancang dan serasi dengan problem dan halayak yang dipilih. ${ }^{27}$

Menurut Sulthon dan Khusnuridla bahwa perubahan yang terjadi dalam pesantren tidak tercerabut dari akar kulturalnya dan tetap mempertahankan tradisi masa lalunya, dan tetap memiliki fungsi sebagai berikut; ${ }^{28} 1$ ) lembaga pendidikan yang melakukan transfer ilmu-ilmu agama dan nilai-nilai Islam. 2) lembaga keagamaan yang melakukan kontrol sosial. 3) lembaga agama yang melakukan rekayasa sosial.

Perubahan seperti yang dilakukan oleh pesantren Tebuireng ini dalam Nurcholish Majid oleh Azyumardi Azra di lakukan secara perlahan dan berhati-hati. Dalam menghadapi semua perubahan dan tantangan itu para eksponen pesantren terlihat tidak tergesa-gesa mentransformasikan kelembagaan pesantren menjadi lembaga pendidikan modern Islam sepenuhnya, tetapi sebaliknya cenderung mempertahankan kebijaksanaan hati-hati, mereka menerima pembaharuan pendidikan Islam hanya dalam skala yang sangat terbatas, sebatas mampu menjamin pesantren bisa tetap survive. ${ }^{29}$

Dalam mengembangkan sumberdaya manusia, pesantren harus mampu menganalisis kompetensi inti sumberdaya manusia yang dimiliki serta dapat mengalokasikannya dengan baik. Agar dapat alokasikannya dengan baik maka pengelola pesantren harus mampu menganalisis kekuatan, kelemahan yang dimiliki serta mampu memanfaatkan peluang yang ada untuk dapat menggempur ancaman yang mengelilinginya. Dalam hal ini manajemen sumberdaya manusia dilakukan berdasarkan analisis SWOT tersebut.

27 A. Halim, Rr. Soehartimi, M. Choirul Arif, A. Sunarto AS. Manajemen Pesantren (Yogyakarta: Pustaka Pesantren, 2009), 117-181.

28 Sulthon dan Khusnuridlo, Manajemen Pondok Pesantren dalam Perspektif Global (Yogyakarta: LaksBang PRESSindo, 2006), 8

${ }^{29}$ Nurcholis Majid, Bilik-bilik Pesantren (Jakarta: Paramadina), xviii

118 | Tarbiyatuna: Jurnal Pendidikan Islam; Volume 13, Nomor 2, Agustus 2020, 107-122 p-ISSN: 2085-6539; e-ISSN: 2242-4579 
Untuk menganalisis sumberdaya manusia bisa menggunakan tehnik sebagai berikut:

\section{Pengamatan (Scanning)}

Pengamatan lingkunag adalah pengamatan sejumlah informasi untuk mendeteksi munculnya kecenderungan dan membuat rencana. Enagan pengamatan lingkungan, perusahaan akan dengan mudah dapat mengetahui keinginan konsumen yang sebenarnya.

\section{Peramalan (Forecasting)}

Teknik kedua dari analisis lingkungan adalah peramalan, kalau dalam tekhnik pengamatan lingkungan informasi yang diperoleh digunakan untuk membuat skenarioskenario, dalam teknik peramalan informasi digunakan untuk membuat anggapananggapan bagi ramalan/forecast, yang memprekdisi hasil.

Untuk memperoleh ramalan yang akurat, maka diperlukan alat bantu sehingga mendapatkan informasi ramalan yang benar sahih dan andal. Untuk itu ada suatu teknik ramalan yang dikelompokan dalam dua kategori yaitu: peramalan kualitatif dan kuantitatif. Peramalan kuatitatif digunakan untuk menerangkan serangkaian kaidah matematis pada serangkaian data masa lalu untuk meramalkan hasil masa depan. Sedangkan peramalan kualitatif penggunaannya didasarkan pada pertimbangan individu-individu yang ahli atau berpengalaman untuk meramalkan hasildi masa depan.

Tabel Analisis Forcasting

\begin{tabular}{|c|c|c|}
\hline $\begin{array}{c}\text { Kategori } \\
\text { Forecasting }\end{array}$ & $\begin{array}{c}\text { Kondisi } \\
\text { sekarang }\end{array}$ & $\begin{array}{c}\text { Kondisi yang } \\
\text { diharapkan }\end{array}$ \\
\hline Kuantitatif & & \\
\hline Kualitatif & & \\
\hline
\end{tabular}

\section{Patok Duga (Benchmarking)}

Patok duga adalah tekhnik pencarian praktek-praktek di antara pesaing yang mengarah pada kinrja mereka yang superior, ide dasar patok duga adalah para manajer dpat memperbaiaki mutu dengan meenganalisis dan kemudian meniru metode keberhasilan perushaan-perudahaan di berbagai bidang. ${ }^{30}$ 
4. External Factor Evaluation (EFE) Matrix Dan Internal Factor Evaluation (IFE) Matrix

Dalam membuat EFF matriks ini, kita mengidentifikasi faktor-faktor eksternal yang menjadi peluang (opportunities) maupun ancaman (trheats). Sedangkan dalam IFE matriks, kita mengidentifikasi faktor-faktor internal berupa kelemahan dan kekuatan. ${ }^{31}$

Table Teknik Analisis EFE dan IFE

\begin{tabular}{|c|l|l|l|}
\hline $\begin{array}{c}\text { Variabel Internal yang } \\
\text { Signifikan }\end{array}$ & Bobot & Rating & Nilai \\
\hline Kekuatan & & & \\
\hline Kelemahan & & & \\
\hline Total & & & \\
\hline
\end{tabular}

5. Artifact dibagi menjadi:

a. Arsitektur lingkungan fisik

b. Bahasa

c. Penggunaan tekhnologi dan produk kreasi artistik

d. Cerita yang dihidupkan

1) Cerita ketokohan dan keteladanan.

2) Cerita kelembagaan.

e. Cara menunjukkan emosi

f. Kegiatan bersama berkaitan dengan aswaja

g. Upacara dan acara

h. Semangat kerja

i. Simbol:

1) Kata-kata

2) Gerak tubuh

3) Jargon

4) Model Pakaian

j. Tokoh yang diidolakan

k. Keteladanan Kiai

6. Nilai yang dipegang teguh contohnya nilai aswaja yang meliputi: tasamuh, tawasut, tawazun, adl dan amar ma'ruf nahi mungkar.

31 Purwanto, Manajemen Strategi, 120

120 | Tarbiyatuna: Jurnal Pendidikan Islam; Volume 13, Nomor 2, Agustus 2020, 107-122 p-ISSN: 2085-6539; e-ISSN: 2242-4579 
7. Asumsi dasar yang mendasari hal ini meliputi keyakinan diri dan ideologi yang dipegang teguh oleh personal pesantren.

\section{Kesimpulan}

Dari diskursus dan dinamika tersebut di atas, dapat diketahui bahwa perubahanperubahan yang terjadi di pesantren sangat berhubungan dengan internal dan eksternal pesantren. Pesantren sejatinya tidak alergi dengan perubahan dari luar, hanya saja pesantren dan seluruh komponen di dalamnya memiliki cara dan teknik sendiri yang menjadi distingsi masing-masiang pesantren. Secara umum, pesantren tidak larut dalam perubahan sosial, pesantren juga tidak pula larut dalam kejumudan. Pesantren memiliki prinsip melihat mengamati dan mengambil, tentu atas dasar maslahat dan mudhorot sebagaimana adagium menjaga tradisi lama yang baik dan mengambil tradisi baru yang baik. Secara konseptual, perubahan pesantren dapat dilakukan dari model dan pola kepemimpinan. Terutama internal pesantren seperti komunikasi antar personal pesatren, melakukan upgrading wawasan internal santri, hingga menetapkan visi strategis. Secara operasional yang lebih banyak bersinggungan dengan eksternal pesantren. Upaya tersebut salah satunya adalah menciptakan image pesantren yang layak jual, hingga melakukan pemetaan perubahan sosial masyarakat untuk menentukan arah dan masa depan pesantren.

\section{Referensi}

A. Halim, Rr. Soehartimi, M. Choirul Arif, A. Sunarto AS. 2009. Manajemen Pesantren. Yogyakarta: Pustaka Pesantren

Amrozi, Shoni Rahmatullah. 2012. The Power Of Rasulullab's Leadership. Yogyakarta: Sabil

Azyumardi Azra, CBE. 2016. Pesantren Masa Kontemporer (Manajemen Sebagai Holding) dalam makalah untuk forum Dosen IAIN Jember

Bagian Perencanaan dan Sistem Informasi, Secretariat Ditjen Pendidikan Islam Kementrian Agama RI, http://www.pendis.kemenag.go.id/

Bruinessen, Martin Van. 2012. Kitab Kuning, Pesantren dan Tarekat. Yogyakarta: Gading Publishing

David Baume dan Peter Kahn. 2004. Enhancing Staff and Educational Development. London: Routledge Falmer

Derektorat Jenderal Kelembagaan Agama Islam. 2003. Pedoman Tatalksana Pengembangan Agri Bisnis Di Pondok Pesantren. Jakarta: Depertemen Agama RI

Direktorat Pendidikan Keagamaan dan Pondok Pesantren Direktorat Jendral Kelembagaan Agama Islam Departemen Agama R.I. Tahun 2004, Pedoman Pengembangan Pesantren dan Pendidikan Keagamaan Tabun 2004-2009

Irwan Prayitno, Datuak Rajo Bandaro Basa. 2005. Kepribadian Dai. Jakarta: Pustaka Tarbiyatuna

James L. Gibson, James H. Donnelly, John N. Ivancevich, Fundamental of Management, Terj. Sularno Tjipto Wardoyo, Imam Nur Wawan. 1997. Management Edisi 9 Jilid 2. Jakarta: Erlangga 
Madjid, Nurcholish. Tt. Bilik-bilik Pesantren. Jakarta: Paramadina

Nurdin, Ali. 2006. Quranic Society. Jakarta: Erlangga

Purwanto, Iwan. 2012. Manajemen Strategi. Bandung: Yrama Widya

Qamar, Mujammil. 2007. Manajemen Pendidikan Islam (Strategi Baru Pengelolaan Lembaga Pendidikan Islam). Jakarta: Erlangga

Soebahar, Abd Halim. 2013. Kebijakan Pendidikan Islam dari Ordonansi Guru sampai UU Sisdiknas. Jakarta: Raja Grafindo Persada

Sulthon dan Khusnuridlo. 2006. Manajemen Pondok Pesantren dalam Perspektif Global. Yogyakarta: LaksBang PRESSindo

Suwito, Fauzan. 2005. Sejarah Sosial Pendidikan Islam. Jakarta: Prenada Media

Turmudzi, Endang. 2004. Perselingkuhan Kiai dan Kekusaan. Yogyakarta: LKiS

Wahid, Abdur Rahman. 1999. Prisma Pemikiran Gus Dur. Yogyakarta: LKiS

2013. Podok Pesantren Masa Depan, Dalam Masdar Hilmy, Pendidikan Islam dan Tradisi Imiah. Surabaya: Pustaka Idea

Web.pendis.kemenag.go.id. Diakses 11/4/2018.

Ziemek, Manfred. 1986. Pesantren dalam Perubahan Sosial, terj. Butche B. Soendjojo. Jakarta: P3M www.jatim.kemenag.go.id.Diakses 11/4/2018 